\title{
Microstructural Evolution at the Bonding Interface during the Early-Stage Infrared Active Brazing of Alumina
}

\begin{abstract}
R.K. SHIUE, S.K. WU, J.M. O, and J.Y. WANG
Infrared brazing of $\mathrm{Al}_{2} \mathrm{O}_{3}$ and alloy 42 using a silver-base active braze alloy was investigated at 900 ${ }^{\circ} \mathrm{C}$ for 0 to 300 seconds, with a heating rate of $3000{ }^{\circ} \mathrm{C} / \mathrm{min}$. Experimental results show that $\mathrm{Ti}_{3}(\mathrm{Cu}$, $\mathrm{Al})_{3} \mathrm{O}$ intermetallic with various amounts of $\mathrm{Al}$ is observed in the reaction layer and plays an important role in the early stage of reactive wetting. A two-layer structure is observed at the reaction interface brazed at $900{ }^{\circ} \mathrm{C}$ for 5 seconds. The reaction layer close to the alumina contains large amounts of $\mathrm{Al}$, so the mass balance of the system is maintained. The growth of the reaction layer is not rate controlled by diffusion within the first 120 seconds. After 120 seconds, the rate controlling mechanism of the reaction layer becomes the diffusion control, satisfying the parabolic law. Dynamic wetting angle measurements using a traditional vacuum furnace at the heating rate of $10{ }^{\circ} \mathrm{C} / \mathrm{min}$ demonstrate that the wetting angle rapidly decreases within the first 150 seconds, especially 0 to 80 seconds, and eventually stabilizes after 600 seconds.
\end{abstract}

\section{INTRODUCTION}

WITH the rapid development of ceramics, superalloys, and composite materials, traditional ways of brazing are insufficient to meet the requirement of joining these materials. Traditional brazes cannot make a good joint between ceramic materials due to the difficulty of wetting, even when their surfaces are clean. ${ }^{[1-4]}$ Most structural ceramics, e.g., alumina, silicon carbide, and zirconia, are chemically more stable than metals, and they will not be wetted by traditional brazes unless the braze contains an active element. Active brazing is a process using a braze filler alloy containing an active element such as $\mathrm{Ti}, \mathrm{Zr}, \mathrm{V}$, and $\mathrm{Cr}^{[2,4,5-10]}$ For example, titanium is one of the most frequently used elements as an active constituent of silver-base active braze alloys. ${ }^{[6,7,9,10]}$ Moreover, the active element in the braze can only be effective if sufficiently high temperatures are used for the joining operation so that the active ingredient is able to react with the ceramics. ${ }^{[2,11]}$ Therefore, the active ingredient plays an important role in active brazing.

The activity of the active element in braze is very important, since it dominates the mechanism of reactive wetting during active brazing. For example, the active element cannot strongly react with other element(s) in the braze alloy, or the activity of the active element may be greatly decreased by formation of intermetallic compounds. Much research has demonstrated that $\mathrm{Ti}$ is an active element in copper and silver-base braze alloys. ${ }^{[7,10,11]}$ The addition of Ti to silver/copper alloys improves the wettability of many ceramics. ${ }^{[12-16]}$ There are many commercially available active braze alloys in use. ${ }^{[4,17]} \mathrm{Ag}-\mathrm{Cu}$ eutectic with $4.5 \mathrm{wt}$ pct $\mathrm{Ti}$ is one of the most popular active silver-base braze alloys used in metal-ceramic joining. ${ }^{[18,19,20]}$

R.K. SHIUE, Assistant Professor, is with the Institute of Materials Science and Engineering, National Dong Hwa University, Hualien 974, Taiwan, Republic of China. S.K. WU, Professor, and J.M. O, former Graduate Student, are with the Institute of Materials Science and Engineering, National Taiwan University, Taipei 106, Taiwan, Republic of China. J.Y. WANG, Deputy Section Head, is with the Materials R\&D Center, Chung-Shan Institute of Science and Technology, Lung-Tan 325, Taiwan, Republic of China.

Manuscript submitted November 29, 1999.
Much research has focused on the interfacial reaction kinetics between active filler alloy and ceramics. ${ }^{[21-25]}$ Most of these studies are performed by traditional electric resistance heating. However, it is difficult to study the interfacial reaction kinetics in the early stage of active brazing if the heating rate of furnace is not fast enough. For instance, the melting point of $\mathrm{Ag}-\mathrm{Cu}$ eutectic alloy is $780{ }^{\circ} \mathrm{C}$. Titanium will be dissolved into $\mathrm{Ag}-\mathrm{Cu}$ eutectic melt for temperatures above $780{ }^{\circ} \mathrm{C}$. The brazing temperature of $\mathrm{Ag}$-Cu eutectic with $4.5 \mathrm{wt}$ pct $\mathrm{Ti}$ alloy is $900{ }^{\circ} \mathrm{C}$. The heating rate of the electric resistance heating furnace is $10^{\circ} \mathrm{C} / \mathrm{min}$, and it takes 720 seconds to reach the brazing temperature. Consequently, the reaction kinetics between 0 and 720 seconds are difficult to be studied in such a furnace. Infrared brazing makes use of infrared energy generated by heating a tungsten filament in a quartz tube as the heating source, providing rapid heating and cooling up to $3000{ }^{\circ} \mathrm{C} / \mathrm{min}$; therefore, infrared brazing is highly suitable in studying the mechanism of early stage reactive wetting. ${ }^{[26,27]}$

The purpose of this investigation is to study the joining of alumina and alloy 42 with $\mathrm{Ag}-\mathrm{Cu}$ - $\mathrm{Ti}$ active filler metal by infrared brazing. The early stage (especially 0 to 300 seconds) of the reactive brazing is studied. The microstructural evolution with various brazing times at the interface between alumina, the braze filler metal, and the active braze itself is examined by scanning transmission electron microscope (STEM) and electron probe microanalysis (EPMA), respectively. The phase(s) at the reaction layer will be identified based on STEM analysis.

\section{EXPERIMENTAL PROCEDURE}

The experimental materials were high-purity alumina (purity $>99.95 \mathrm{pct}$ ) and alloy $42(42 \mathrm{Ni}-58 \mathrm{Fe}$ in wt pct). The active filler braze was TICUSIL, ${ }^{*} 68.8 \mathrm{Ag}-26.7 \mathrm{Cu}-4.5 \mathrm{Ti}$

*TICUSIL is a trademark of Wesg. Co., Belmont, CA 94002.

in wt pct. The dimensions of alloy 42 were $10 \times 10 \times 2$ $\mathrm{mm}$. The size of the alumina disk was $10 \mathrm{~mm}$ in diameter and $2 \mathrm{~mm}$ in thickness. The thickness of TICUSIL foil was 

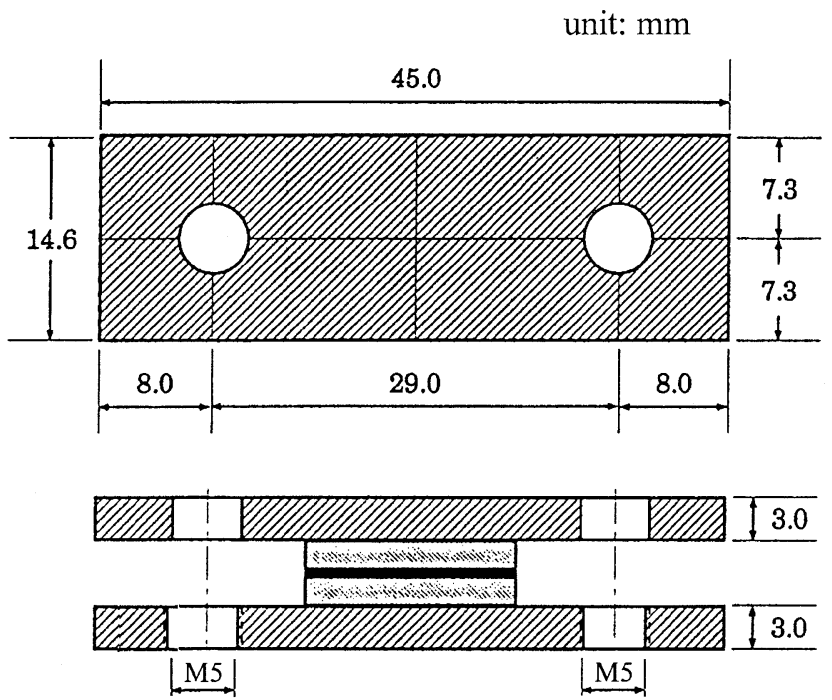

Fig. 1-Schematic diagrams showing the geometry of graphite fixture in the test.

$50 \mu \mathrm{m}$ throughout the experiment. The alloy 42 surfaces were first polished by $\mathrm{SiC}$ paper and subsequently polished by $1,0.3$, and $0.05 \mu \mathrm{m}$ alumina powder. All alumina surfaces were polished using $1 \mu \mathrm{m}$ diamond paste. An ultrasonic bath using acetone as the solvent was used to clean samples prior to brazing. Infrared brazing was performed in a vacuum of $5 \times 10^{-3} \mathrm{~Pa}$ at a temperature of $900{ }^{\circ} \mathrm{C}$ for $5,10,20$, $40,60,80,120,150,180,240$, and 300 seconds. The heating rate of the infrared furnace was set at $3000^{\circ} \mathrm{C} / \mathrm{min}$ throughout the experiment.

To enhance infrared absorption of the specimen, a graphite fixture was used during brazing, as displayed in Figure 1. Specimens were sandwiched between two graphite plates, and the thermal couple was inserted into the graphite plate. There is a time delay between the actual specimen temperature and programmer temperature. Figure 2(a) shows the heating cycle of 60 seconds without time compensation. It is clear that the actual holding time is less than 60 seconds in the figure. Figure 2(b) displays the same cycle with time compensation. The time delay will have a strong effect in the test if the brazing time is short, such as 5 seconds. Therefore, time compensation during the infrared brazing was included for all tests in this study.

Dynamic wetting angle measurements were made using a traditional resistance vacuum furnace at the temperature range between $880{ }^{\circ} \mathrm{C}$ and $900{ }^{\circ} \mathrm{C}$ for 0 to 1800 seconds. Samples of $0.15 \mathrm{~g}$ TICUSIL were prepared from its foil by vacuum arc remelting. A TICUSIL sample was put on the alumina disk in vacuum furnace for wetting angle measurements. The heating rate of the furnace was set at $10{ }^{\circ} \mathrm{C} / \mathrm{min}$ throughout the experiment.

The brazed specimens were cut by a low speed diamond saw. An etching solution $2 \mathrm{~g} \mathrm{FeCl}_{3}+30 \mathrm{~mL} \mathrm{H}_{2} \mathrm{O}+10$ $\mathrm{mL} \mathrm{HCl}+60 \mathrm{~mL} \mathrm{C}_{2} \mathrm{H}_{5} \mathrm{OH}$ was used for metallographic examination. The cross-polished section of the brazed specimens was examined using a PHILIPS* XL30 SEM, and

*PHILIPS is a trademark of Philips Electronic Instruments Corp., Mahwah, NJ.

quantitative chemical analysis was performed using a

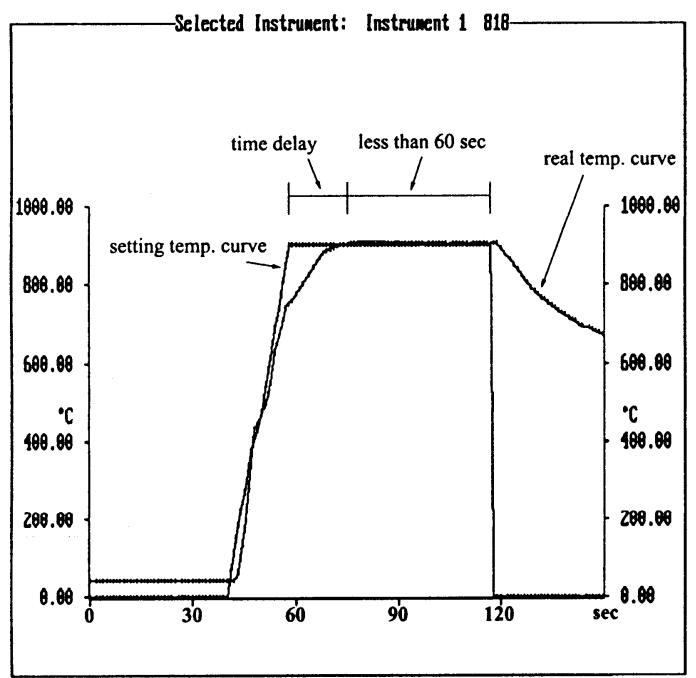

(a)

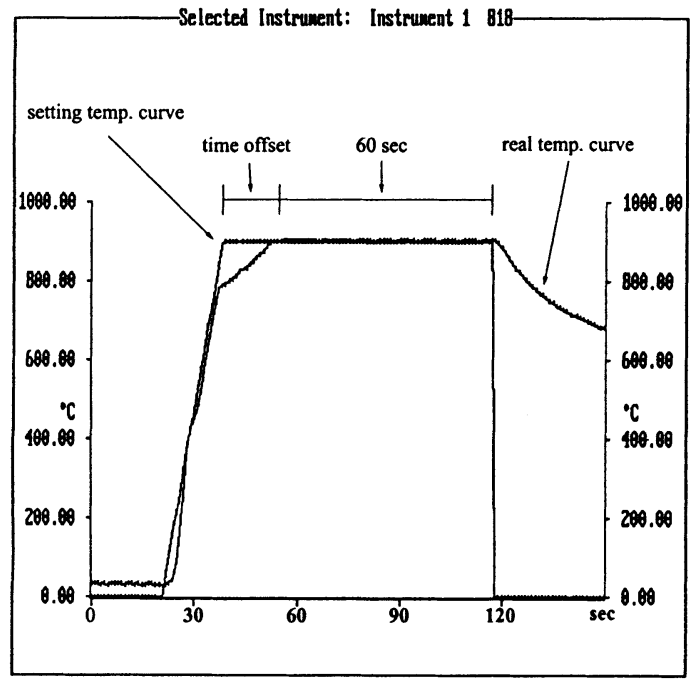

(b)

Fig. 2-The thermal cycle of $60 \mathrm{~s}$ heating: (a) without time compensation and $(b)$ with time compensation

JEOL** JXL-8600SX EPMA. All samples were carbon

**JEOL is a trademark of Japan Electron Optics Ltd., Tokyo.

coated before SEM or EPMA examination. A JEOL JEM4000FX STEM equipped with an energy-dispersive spectroscope (EDS) was used for both structural and chemical analysis of the interface between TICUSIL and alumina, using an accelerating voltage of $400 \mathrm{kV}$. All STEM specimens were dimple ground using $0.25 \mu \mathrm{m}$ diamond paste, followed by ion mill sharpening.

\section{RESULTS AND DISCUSSIONS}

\section{A. Metallographic Observations of the Active Filler Metal}

Figure 3 displays the SEM backscattered electron images of the brazed joint after infrared brazing for 5, 20, 60, 120, 180 , and 300 seconds. Six phases are found in the braze filler metal, excluding the reaction layer, and they are shown 

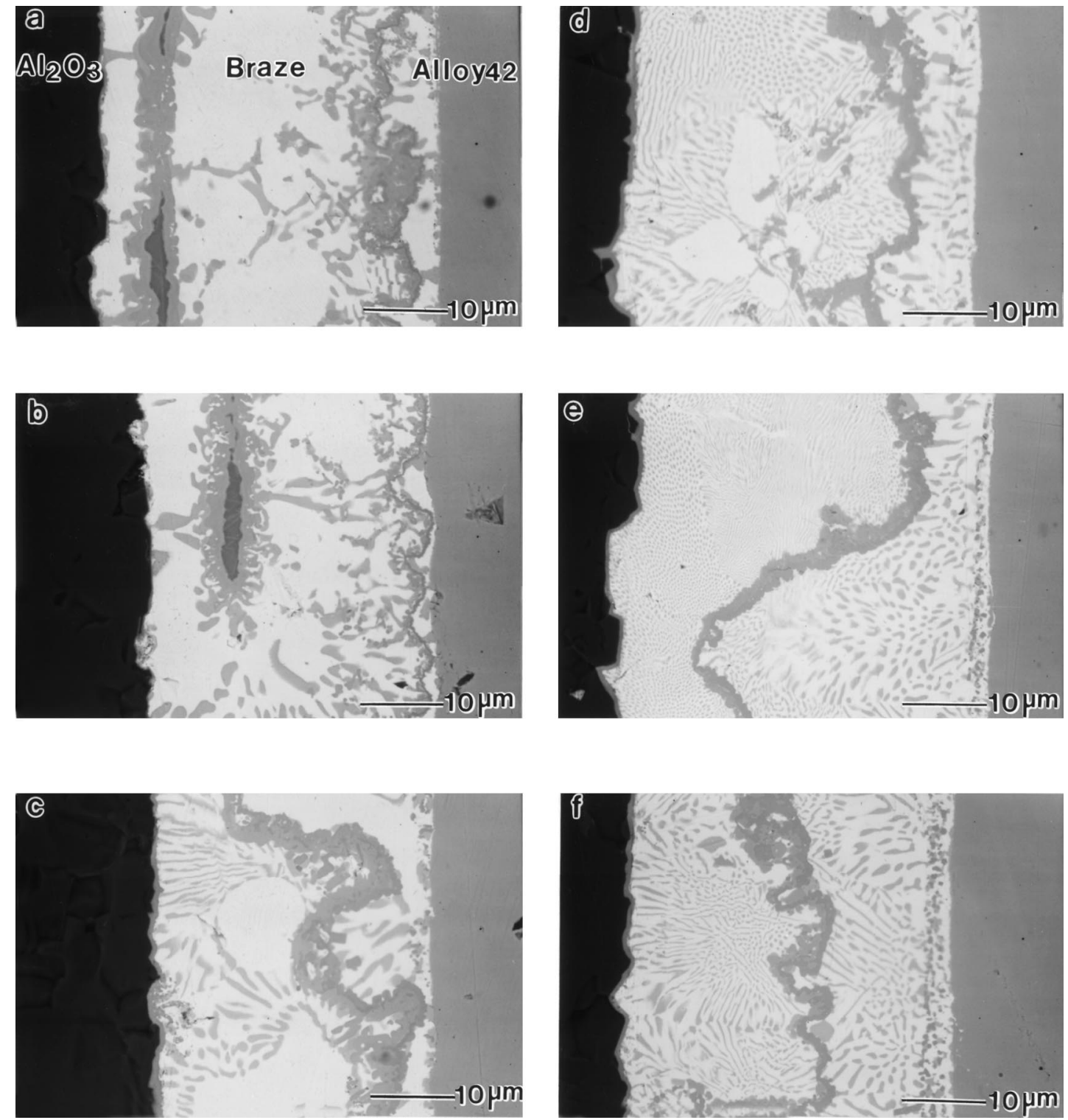

Fig. 3-The SEM backscattered electron images of the braze joint after infrared brazing for $(a) 5,(b) 20,(c) 60,(d) 120,(e) 180$, and $(f) 300 \mathrm{~s}$.

in Table I: (A) silver-rich solid solution with $6.5 \mathrm{wt}$ pct copper, (B) silver-copper eutectic solid solution with $1.9 \mathrm{wt}$ pct titanium, (C) copper-rich alloy phase, (D) iron-rich alloy phase, (E) $\mathrm{Cu}$-Ti alloy solid solution with $4.0 \mathrm{wt}$ pct silver, and (F) titanium matrix solid solution with $4.1 \mathrm{wt}$ pet copper. The chemical composition of $\mathrm{E}$ phase in Table I is very close to that of $\mathrm{Cu}_{4} \mathrm{Ti}_{3}$ phase according to the $\mathrm{Cu}-\mathrm{Ti}$ phase diagram. ${ }^{[28,29]}$

According to the experimental results, the microstructural evolution of the braze filler metal can be divided into several stages over the time period of 0 to 300 seconds. If the brazing time is less than 40 seconds, all six phases can be found in the braze, as shown in Figures 3(a) and (b), although the braze is primarily comprised of phases A and B. Phase F is totally enclosed by phase $\mathrm{E}$, and the volume fraction of both phases is decreased with increasing brazing time. Phases $\mathrm{C}$ and $\mathrm{D}$ are observed at the locations close to alloy 42 , and they have a chainlike morphology. For specimens brazed between 40 and 180 seconds, there are only four phases, A, $\mathrm{B}, \mathrm{C}$, and $\mathrm{D}$, observed in the filler metal, with both $\mathrm{E}$ and
F phases having disappeared. With increased brazing time, phase $\mathrm{A}$ is replaced by phase $\mathrm{B}$ and phases $\mathrm{C}$ and $\mathrm{D}$ move toward the reaction layer between alumina and active braze filler metal. If the brazing time exceeds 180 seconds, only $\mathrm{B}, \mathrm{C}$, and D phases are found in the SEM observation. A summary of the microstructural evolution in the braze alloy for various brazing times is shown in Table II.

The Ti distribution in TICUSIL foil is not uniform, and the SEM inspection shows a long Ti wire in the foil, as illustrated in Figure 4. Therefore, there was insufficient time to dissolve all the Ti into the active braze filler metal with a brazing time below 40 seconds. As the brazing time is increased, all of the Ti is dissolved into braze. The melting point of pure $\mathrm{Ti}$ is much higher than that of the $\mathrm{Ag}-\mathrm{Cu}-\mathrm{Ti}$ braze. By dissolving the titanium into solution, the titanium transport is greatly enhanced. Titanium could react with alloy 42 (Fe-Ni alloy) to form phases $\mathrm{C}$ and $\mathrm{D}$. Meanwhile, Ti would also be transported into the interface between the alumina and the braze alloy to form a reaction layer. It has also been reported that Ti is associated with copper in 
Table I. The Chemical Analysis of Different Phases in Figure 3

\begin{tabular}{|c|c|c|c|c|c|c|}
\hline & & $\mathrm{Ag}$ & $\mathrm{Cu}$ & $\mathrm{Ti}$ & $\mathrm{Fe}$ & $\mathrm{Ni}$ \\
\hline \multirow[t]{2}{*}{ A } & wt pct & 93.5 & 6.5 & - & - & - \\
\hline & at. pct & 89.5 & 10.5 & - & - & - \\
\hline \multirow[t]{2}{*}{ B } & wt pct & 65.5 & 32.6 & 1.9 & - & - \\
\hline & at. pct & 52.4 & 44.3 & 3.3 & - & - \\
\hline \multirow[t]{2}{*}{$\mathrm{C}$} & wt pct & - & 56.9 & 24.2 & 2.4 & 16.5 \\
\hline & at. pct & - & 51.9 & 29.3 & 2.5 & 16.3 \\
\hline \multirow[t]{2}{*}{ D } & wt pct & - & - & 27.7 & 55.7 & 16.6 \\
\hline & at. pct & - & - & 31.2 & 53.6 & 15.2 \\
\hline \multirow[t]{2}{*}{$\mathrm{E}$} & wt pct & 4.0 & 59.7 & 36.3 & - & - \\
\hline & at. pct & 2.2 & 54.1 & 43.7 & - & \\
\hline \multirow[t]{2}{*}{$\mathrm{F}$} & wt pct & - & 4.1 & 95.9 & - & - \\
\hline & at. pct & - & 3.1 & 96.9 & - & - \\
\hline
\end{tabular}

TICUSIL melt during brazing. ${ }^{[29]}$ The consumption of Ti in the melt due to the reactions with other elements would result in decomposition of $\mathrm{Cu}-\mathrm{Ti}$ compound in the melt and the simultaneous release of $\mathrm{Cu}$ into the melt. Therefore, the volume fraction of $\mathrm{Ag}-\mathrm{Cu}$ eutectic phase is increased after brazing. The area of silver-rich matrix decreases with increasing brazing time, as shown in Figure 3. The microstructural evolution is completed at 180 seconds, since there is no silver-rich matrix, as shown in Figure 3(e).

\section{B. The Interfacial Reaction between Alumina and Active Braze}

Figure 5 shows the SEM backscattered electron image of the reaction layer between alumina and active filler metal brazed at $900{ }^{\circ} \mathrm{C}$ for $5,20,60,120,180$, and 300 seconds, respectively. Figure 6 shows the relation between the reaction layer thickness and brazing time at the alumina/ TICUSIL interface. If the growth of reaction layer is rate controlled by the same diffusion mechanism, it should be governed by the parabolic growth law of the reaction layer: ${ }^{[30,31]}$

$$
x=\left(k_{p} t\right)^{1 / 2}
$$

where $x$ is reaction layer thickness, $t$ is reaction time, and $k_{p}$ is the parabolic growth rate constant. In other words,

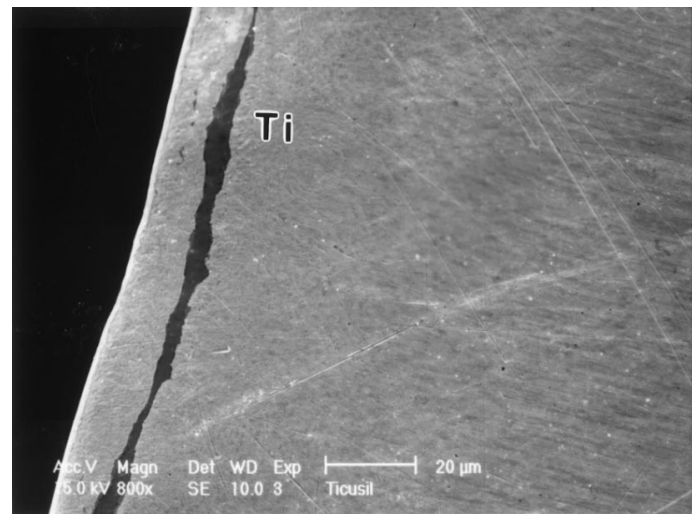

Fig. 4-SEM inspection of TICUSIL foil used in the experiment.

$x^{2} / t$ should approach a constant value for a fixed diffusioncontrolled growth. Figure 7 demonstrates the relationship between $x^{2} / t$ and $t$. The value of $x^{2} / t$ approaches a constant for the brazing time greater than 120 seconds. Therefore, the growth kinetics of the reaction layer is rate controlled by diffusion at times greater than 120 seconds. On the other hand, the growth of reaction layer is not consistent with the mechanism of rate controlling by diffusion if the brazing time is less than 80 seconds. The growth kinetics of the reaction layer for short brazing times cannot be identified in the experiment and needs further study.

Figure 8 shows the dynamic wetting angle measurements in the sessile drop experiments of TICUSIL brazed on alumina for various brazing temperatures using a traditional vacuum furnace at a heating rate of $10{ }^{\circ} \mathrm{C} / \mathrm{min}$. The higher the brazing temperature, the lower the dynamic wetting angle that can be obtained. The dynamic wetting angle of the specimen tested at $900{ }^{\circ} \mathrm{C}$ is 5 to $20 \mathrm{deg}$ lower than that of the specimen tested at $880{ }^{\circ} \mathrm{C}$. The experimental data demonstrate that the wetting angle rapidly decreases within the first 150 seconds, especially within 0 to 80 seconds. The wetting angle is stabilized if the brazing time exceeds 600 seconds. As discussed earlier, the growth kinetics of the reaction layer is rate controlled by diffusion for long brazing times. The transport of Ti into the interface becomes slower due to the increased thickness of the interface. It is noted that the wetting angle observations are not consistent with the Ti distribution, especially at 0 to 180 seconds, as described in Section A. It primarily results from the slow heating rate, $10^{\circ} \mathrm{C} / \mathrm{min}$, of the electric heating furnace used in the wetting angle measurement.

Much research has been focused on modeling the kinetics

Table II. Summary of the Microstructural Evolution in the Braze Alloy for Various Brazing Times

\begin{tabular}{|c|c|c|c|}
\hline Phase & 0 to $40 \mathrm{~s}$ & 40 to $180 \mathrm{~s}$ & 180 to $300 \mathrm{~s}$ \\
\hline $\begin{array}{l}\text { Phase A: Ag-rich solid solution with } 6.5 \mathrm{wt} \\
\text { pet } \mathrm{Cu}\end{array}$ & exist (primary phase) & exist (gradually replaced by phase B) & disappear \\
\hline $\begin{array}{l}\text { Phase } \mathrm{B}: \mathrm{Ag}-\mathrm{Cu} \text { eutectic solid solution with } \\
1.9 \text { wt pct } \mathrm{Ti}\end{array}$ & exist (primary phase) & exist (primary phase) & exist (primary phase) \\
\hline Phase C: Cu-rich alloy phase & exist & exist & exist \\
\hline Phase D: Fe-rich alloy phase & exist & exist & exist \\
\hline $\begin{array}{l}\text { Phase E: Cu-Ti alloy solid solution with } 4 \\
\text { wt pct } \mathrm{Ag}\end{array}$ & exist & disappear & disappear \\
\hline $\begin{array}{l}\text { Phase F: Ti matrix solid solution with } 4.1 \\
\text { wt pet } \mathrm{Cu}\end{array}$ & exist (enclosed by phase E) & disappear & disappear \\
\hline
\end{tabular}



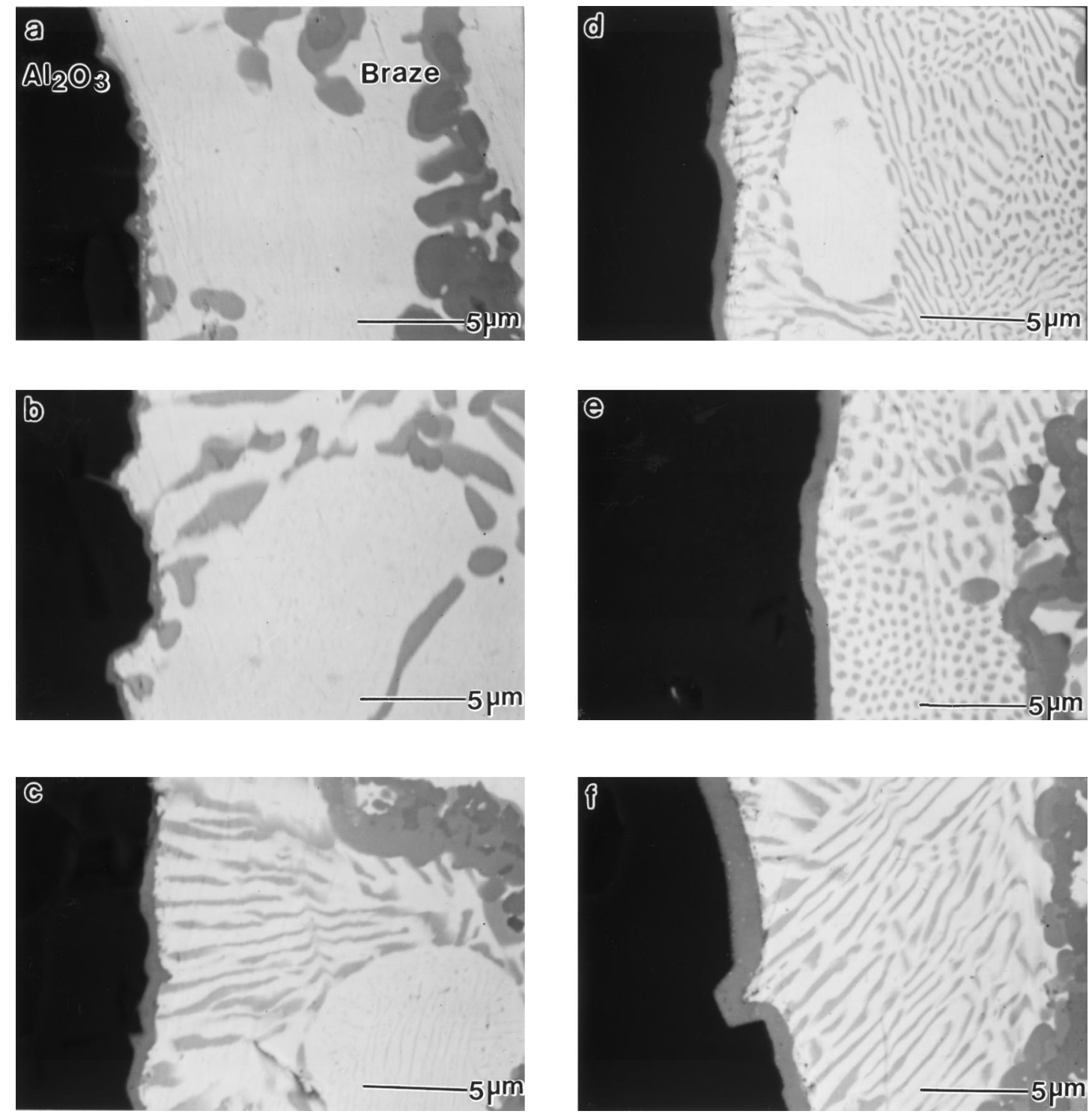

Fig. 5-The SEM backscattered electron image of the reaction layer between alumina and active filler metal brazing at $900{ }^{\circ} \mathrm{C}$ for $(a) 5,(b) 20,(c) 60$, (d) 120, (e) 180, and $(f) 300 \mathrm{~s}$.

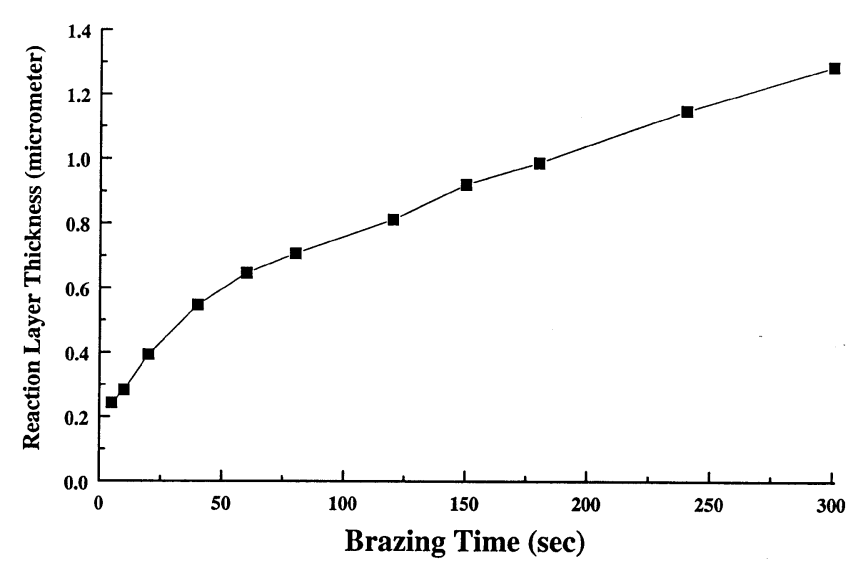

Fig. 6-The relation between the reaction layer thickness and brazing time at the alumina/TICUSIL interface.

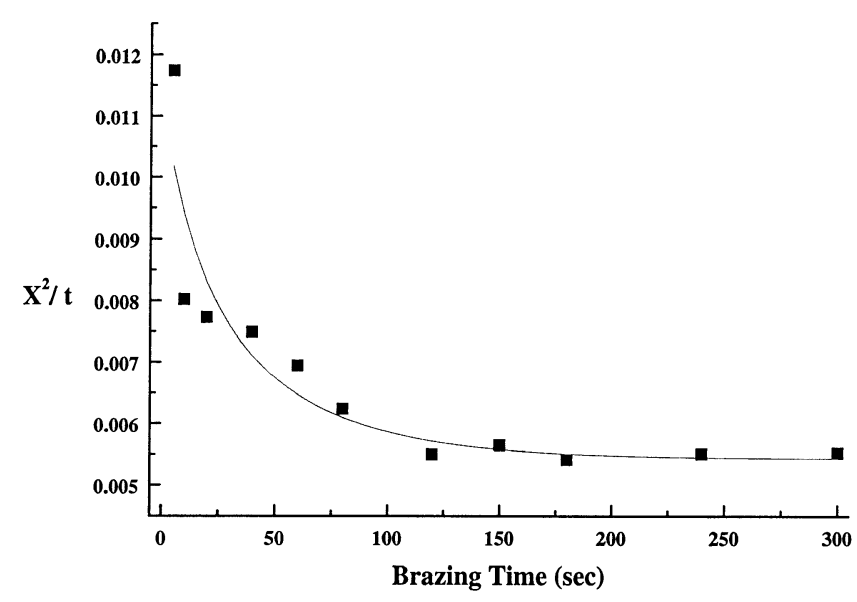

Fig. 7-The relation between $x^{2} / t$ and $t$ at $900{ }^{\circ} \mathrm{C}$. 


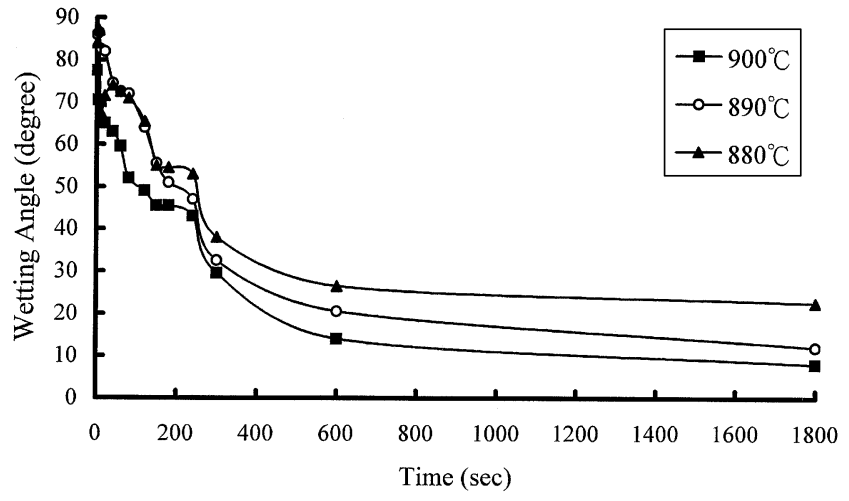

Fig. 8- The dynamic wetting angle measurement of TICUSIL braze on alumina for various brazing temperatures by using a traditional vacuum furnace at the heating rate of $10{ }^{\circ} \mathrm{C} / \mathrm{min}$.

of the reactive wetting in metal/ceramic systems. ${ }^{[21,32-34]}$ Eustathopoulos ${ }^{[34]}$ proposed that there are three possible ratelimiting mechanisms in reactive wetting: viscous flow, diffusion within the sessile drop, and chemical kinetics at the triple line. He concluded that reactive wetting is not rate limited by viscous flow due to the low viscosity of molten metal. The final contact angle in a reactive system is given with good accuracy by the equilibrium contact angle of the liquid on the reaction product. This is consistent with our experimental observations. The reaction layer rapidly becomes continuous, and it isolates the alumina and the braze filler metal, as shown in Figure 5. Therefore, the reactive wetting is rate controlled by either transport or chemical reaction of the reactive element at the interface.

Figures 9(a) and (b) display the results of EPMA line scan analysis across the alumina/TICUSIL interface brazed at $900{ }^{\circ} \mathrm{C}$ for 5 and 80 seconds, respectively. The interface is enriched in $\mathrm{Ti}$ and $\mathrm{Cu}$ for both the 5- and 80-second specimens, but $\mathrm{Ag}$ is not found at the interface. The Fe and $\mathrm{Ni}$ enrichment at the interface for the 5-second specimen is observed, and it becomes more prominent for the 80 -second specimen. Since most diffusion coefficients in liquid metals have the same order of magnitude, $10^{-8}$ to $10^{-9} \mathrm{~m}^{2} / \mathrm{s}$, the diffusion distance of $\mathrm{Ni}$ and $\mathrm{Fe}$ atoms in braze melt can be approximated by the square root of $D t .^{[35]}$ Thus, the diffusion distance of $\mathrm{Ni}$ and $\mathrm{Fe}$ atoms in the melt for 5 seconds is approximately 70 to $220 \mu \mathrm{m}$, which is much larger than the thickness of braze filler metal, $50 \mu \mathrm{m}$. This feature is consistent with our experimental observation that both $\mathrm{Fe}$ and $\mathrm{Ni}$ atoms have dissolved into the braze melt at $900{ }^{\circ} \mathrm{C}$ for 5 seconds.

The minimum spot size of the EPMA in this study is about $1 \mu \mathrm{m}$. Namely, the actual sampling volume is usually much greater than $1 \mu \mathrm{m}$ in diameter. However, the thickness of reaction layer is less than $1 \mu \mathrm{m}$ for specimens brazed less than 180 seconds. High-resolution STEM + EDS inspection is necessary in order to analyze the structure and chemical composition of the reaction layer. The spot size of EDS used in this study is $20 \mathrm{~nm}$, which is much smaller than the observed reaction layer. The diameter of aperture size in the selected area diffraction pattern (SADP) analysis is $1 \mu \mathrm{m}$, which is greater than the reaction layer thickness of the specimen brazed at $900{ }^{\circ} \mathrm{C}$ for 5 seconds. Figure 10 shows the STEM + EDS analysis of the alumina/TICUSIL interface brazed at $900{ }^{\circ} \mathrm{C}$ for 5 seconds. Since the EDS analysis cannot identify oxygen atoms, the oxygen content is not included in this analysis. Based on the chemical analysis, the atomic ratio between $\mathrm{Ti}$ and $(\mathrm{Cu}, \mathrm{Al})$ is very close to $1: 1$. Some interfaces contain two reaction layers, as shown in Figure 11. Based on the SADP analysis together with the EDS result, shown in Figures 11(b) and (c), respectively, point $\mathrm{B}$ can be identified as the $\mathrm{Ti}_{3}(\mathrm{Cu}, \mathrm{Al})_{3} \mathrm{O}$ phase. Figure 12 is the TEM analysis of the alumina/TICUSIL interface brazed at $900{ }^{\circ} \mathrm{C}$ for 20 seconds. A similar atomic $\mathrm{Ti} /(\mathrm{Cu}$, $\mathrm{Al})$ ratio is observed, and some $\mathrm{Fe}$ and $\mathrm{Ni}$ are found at the reaction layer. It is consistent with the previous EPMA analysis shown in Figure 9. Figure 13 shows the STEM + EDS analysis of the interface brazed at $900{ }^{\circ} \mathrm{C}$ for 300 seconds, where two layers can be observed. However, the atomic ratio between $\mathrm{Ti}$ and $(\mathrm{Cu}, \mathrm{Al})$ is changed in both layers, with huge amounts of $\mathrm{Fe}$ and $\mathrm{Ni}$ being observed in the reaction layers.

Many researchers have contributed to the understanding of metal-ceramic interfaces. ${ }^{[36-47]} \mathrm{Carim}^{[43]}$ found that compounds with stoichiometry $\mathrm{M}_{6} \mathrm{X}(\mathrm{M}=\operatorname{metal}(\mathrm{s}), \mathrm{X}=\mathrm{B}, \mathrm{C}$, $\mathrm{N}$, or $\mathrm{O}$ ) of the $\eta$ group are observed at a number of metalceramic interfaces, especially in the reaction layer of ceramics brazed with Ti-containing active filler metals. Two different specific compounds, $\mathrm{M}_{4}^{\mathrm{I}} \mathrm{M}_{2}^{\mathrm{II}} \mathrm{X}$ and $\mathrm{M}_{3}{ }_{3} \mathrm{M}_{3}^{\mathrm{II}} \mathrm{X}$, could be found in the reaction layer. For instance, both $\mathrm{Ti}_{4} \mathrm{Cu}_{2} \mathrm{O}$ and $\mathrm{Ti}_{3} \mathrm{Cu}_{3} \mathrm{O}$ intermetallics can be formed after brazing. This has been supported by many other experimental results in active brazing of alumina. ${ }^{[44-47]}$ Based on the STEM + EDS analysis in this study, a $\mathrm{Ti}_{3}(\mathrm{Cu}, \mathrm{Al})_{3} \mathrm{O}$ phase is formed at the very early stage ( 5 and 20 seconds) of active brazing alumina. It has been reported that $\mathrm{Al}$ could dissolve easily in the $\mathrm{Ti}_{3} \mathrm{Cu}_{3} \mathrm{O}$ type compound, which is consistent with our study. ${ }^{[46,48]}$ The Al content in the reaction layer close to alumina is high, as shown in Figures 11(a) and (c). However, the titanium oxides such as $\mathrm{TiO}, \mathrm{Ti}_{2} \mathrm{O}$, and $\mathrm{Ti}_{3} \mathrm{O}_{2}$ reported in other research are not observed in this study. ${ }^{[45,46]}$

\section{Reaction Mechanism of Infrared Active Brazing Alumina}

Ternary alloy phase diagrams only describe the phase evolution of an equilibrium system. The Ti in the active filler metal reacts with other elements during infrared brazing, and the phases in the braze may not reach equilibrium due to the fast infrared heating process. Therefore, the phase change in the process cannot be precisely described by the phase diagram. However, a ternary phase diagram of $\mathrm{Ag}-\mathrm{Cu}-\mathrm{Ti}$ could still provide some basic information for the system. Figure 14 displays the liquidus surface of $\mathrm{Ag}-\mathrm{Cu}$-Ti ternary phase diagram. ${ }^{[29]}$ The active filler metal used in this study has a chemical composition of $55.3 \mathrm{Ag}-36.5 \mathrm{Cu}-8.2 \mathrm{Ti}$ in atomic percent. According to the figure, there are two immisible liquids, $\mathrm{L}_{1}{ }_{1}$ and $\mathrm{L}_{2}{ }_{2}$, in the melt at $900{ }^{\circ} \mathrm{C}$. ${ }^{[4]}$ The liquid $\mathrm{L}_{1}{ }_{1}$ is $\mathrm{Cu} / \mathrm{Ti}$-rich phase with the chemical composition of 63Cu-32Ti-5Ag (at. pct); and $\mathrm{L}_{2}{ }_{2}$ is Ag-rich phase with the chemical composition of $68 \mathrm{Ag}-30 \mathrm{Cu}-2 \mathrm{Ti}$ (at. pct). The equilibrium equation at $900^{\circ} \mathrm{Cis}$ shown as follows:

$$
\mathrm{L}_{1}+\mathrm{CuTi} \leftrightarrow \mathrm{L}_{2}+\mathrm{Cu}_{4} \mathrm{Ti}_{3}
$$

If the cooling path follows the liquidus projection of the 

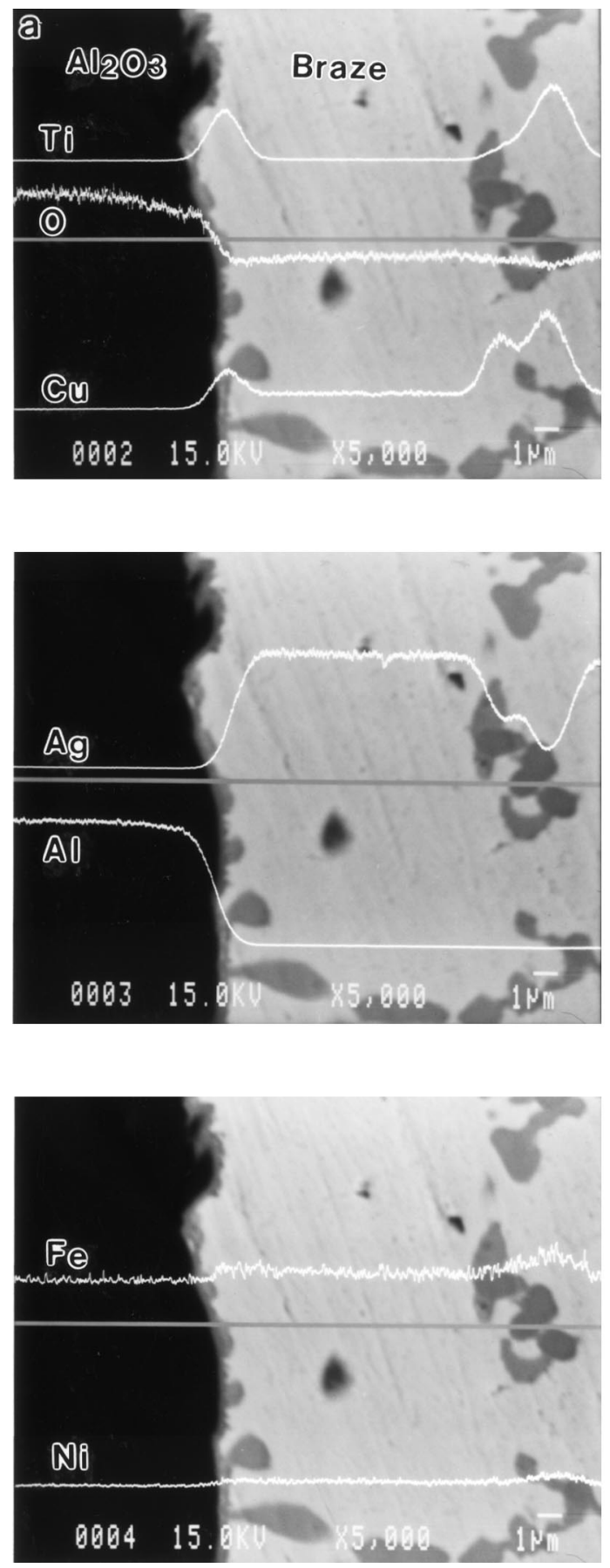
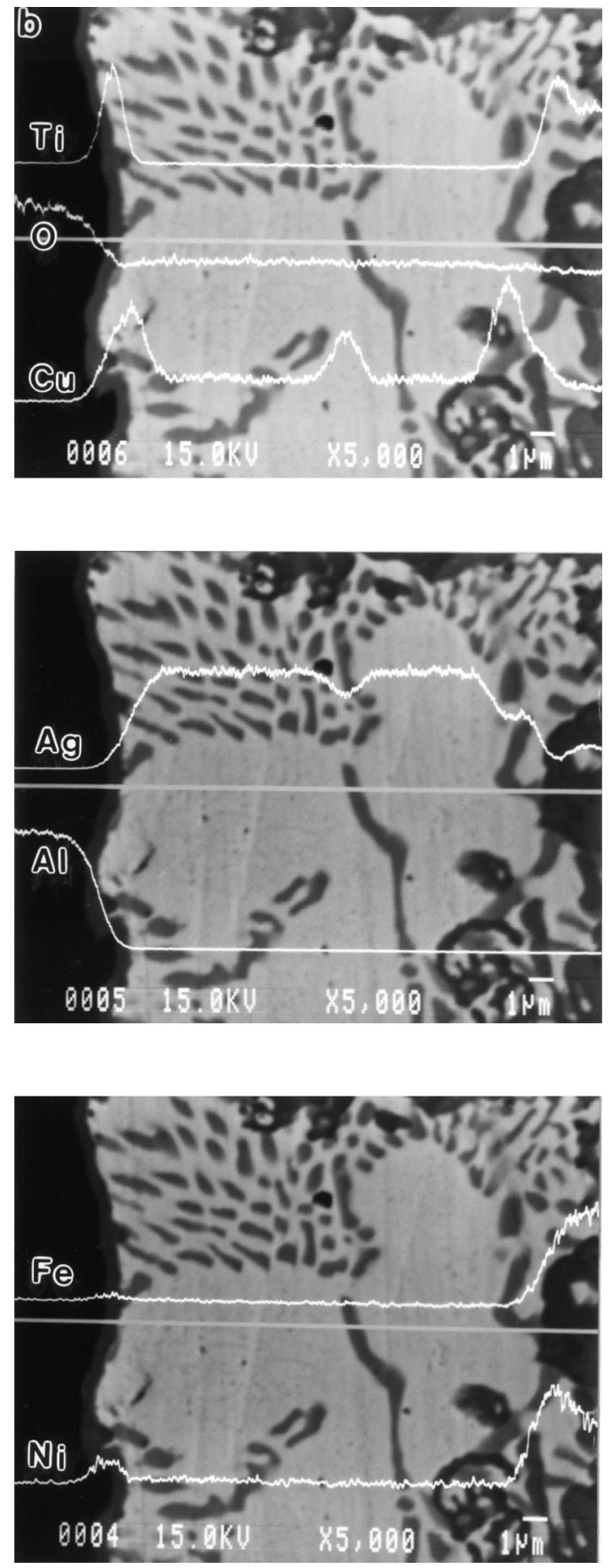

Fig. 9-EPMA line scan analysis of alumina/TICUSIL interface brazing at $900{ }^{\circ} \mathrm{C}$ for $(a) 5$ and $(b) 80 \mathrm{~s}$.

ternary phase diagram displayed in Figure 14, the equilibrium at $c_{1}$, about $850{ }^{\circ} \mathrm{C}$, would be reached as follows: ${ }^{[29]}$

$$
\mathrm{L} \leftrightarrow \mathrm{Cu}_{4} \mathrm{Ti}_{3} \text { (liquid equilibrates with } \mathrm{Cu}_{4} \mathrm{Ti}_{3} \text { ) }
$$

As discussed earlier, phase $\mathrm{E}$ in Table $\mathrm{I}$ is observed at the initial stage (0 to 40 seconds) of infrared brazing, and its

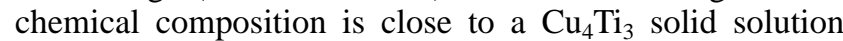
with minor Ag, according to EDS analysis. This is consistent with the phase diagram and can explain the microstructural evolution of the braze alloy at the initial stage.

The reactive wetting of alumina primarily depends on $\mathrm{Cu} /$ Ti-rich liquid, $\mathrm{L}_{1}{ }_{1}$, at $900{ }^{\circ} \mathrm{C}$. This reacts with alumina and forms $\mathrm{Ti}_{3}(\mathrm{Cu}, \mathrm{Al})_{3} \mathrm{O}$ at the reaction layer. Barbier et al. ${ }^{[45]}$ proposed that the $\mathrm{Ti}_{3} \mathrm{Cu}_{3} \mathrm{O}$ layer acts as a wettable surface promoting bonding between alumina and active filler metal. This characteristic is consistent with our results that the dynamic wetting angle rapidly decreases at the beginning of reactive wetting. $\mathrm{Ti}_{3}(\mathrm{Cu}, \mathrm{Al})_{3} \mathrm{O}$ phase is identified in STEM examination at the very early stage (5 seconds) of brazing, and no titanium oxides are observed in the study. In addition to providing a wettable surface, $\mathrm{Ti}_{3}(\mathrm{Cu}, \mathrm{Al})_{3} \mathrm{O}$ could also form a solid solution with a very large amount of aluminum that is rejected from the reaction of alumina. ${ }^{[46,48]}$ It is essential that sufficient aluminum be found 


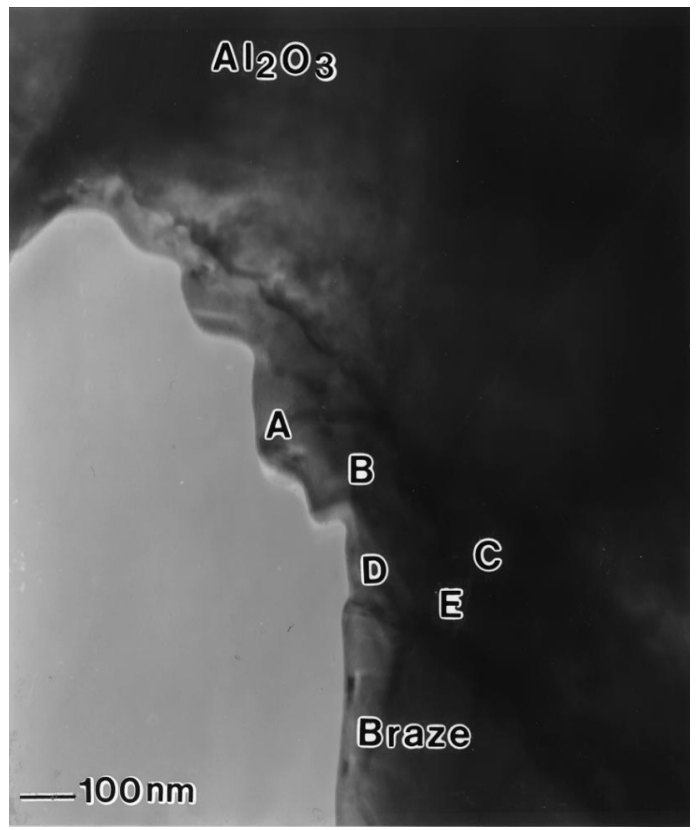

(a)

\begin{tabular}{ccccccc}
\hline Point & $\mathrm{Cu}$ & $\mathrm{Ti}$ & $\mathrm{Al}$ & $\mathrm{Ag}$ & $\mathrm{Fe}$ & $\mathrm{Ni}$ \\
\hline $\mathrm{A}($ at \%) & 44.3 & 51.8 & 3.4 & 0.5 & - & - \\
$\mathrm{B}($ at \%) & 45.4 & 49.9 & 3.9 & 0.8 & - & - \\
$\mathrm{C}($ at \%) & 44.5 & 49.9 & 4.0 & 1.6 & - & - \\
$\mathrm{D}($ at \%) & 43.2 & 50.2 & 4.4 & - & 0.9 & 1.3 \\
$\mathrm{E}($ at \%) & 43.9 & 50.1 & 3.8 & - & 1.0 & 1.2 \\
\hline
\end{tabular}

(b)

Fig. 10-STEM + EDS analysis of the alumina/TICUSIL interface brazed at $900{ }^{\circ} \mathrm{C}$ for $5 \mathrm{~s}$ : (a) bright field; and (b) EDS analysis of points A, B, $\mathrm{C}, \mathrm{D}$, and $\mathrm{E}$ marked in part (a).

in the reaction layers in order to maintain the mass balance in the system. The formation of the $\mathrm{Ti}_{3}(\mathrm{Cu}, \mathrm{Al})_{3} \mathrm{O}$ reaction layer can dissolve the aluminum atoms rejected from the interface of reaction between alumina and braze. With increasing of brazing time, the dissolution of alloy 42 occurs. In addition, $\mathrm{Fe}$ and $\mathrm{Ni}$ atoms react with the braze and take part in the reaction layer. Therefore, the chemical composition of the reaction layer deviates from $\mathrm{Ti}_{3}(\mathrm{Cu}, \mathrm{Al})_{3} \mathrm{O}$, as demonstrated in Figure 13.

\section{CONCLUSIONS}

Based on the characteristics of rapid heating by an infrared furnace, the joining of $\mathrm{Al}_{2} \mathrm{O}_{3}$ and alloy 42 using a silverbase active braze alloy at $900{ }^{\circ} \mathrm{C}$ for 0 to 300 seconds is investigated. The heating rate is set at $3000{ }^{\circ} \mathrm{C} / \mathrm{min}$ during infrared joining. The conclusions drawn are as follows.

1. The microstructural evolution of the braze filler metal is divided into several stages. First, the Ti wires of the filler metal are completely dissolved into the braze melt in less than 40 seconds, forming $\mathrm{Ag} / \mathrm{Cu} / \mathrm{Ti}, \mathrm{Cu} / \mathrm{Ti} / \mathrm{Ni} / \mathrm{Fe}, \mathrm{Fe} / \mathrm{Ti} /$ $\mathrm{Ni}$, and $\mathrm{Cu} / \mathrm{Ti}$ phases. Second, the silver-rich matrix is replaced by silver-copper eutectic matrix, and the reaction products, $\mathrm{Cu} / \mathrm{Ti} / \mathrm{Ni} / \mathrm{Fe}$ and $\mathrm{Fe} / \mathrm{Ti} / \mathrm{Ni}$ phases, grow continuously. Finally, all the silver matrix is totally replaced by

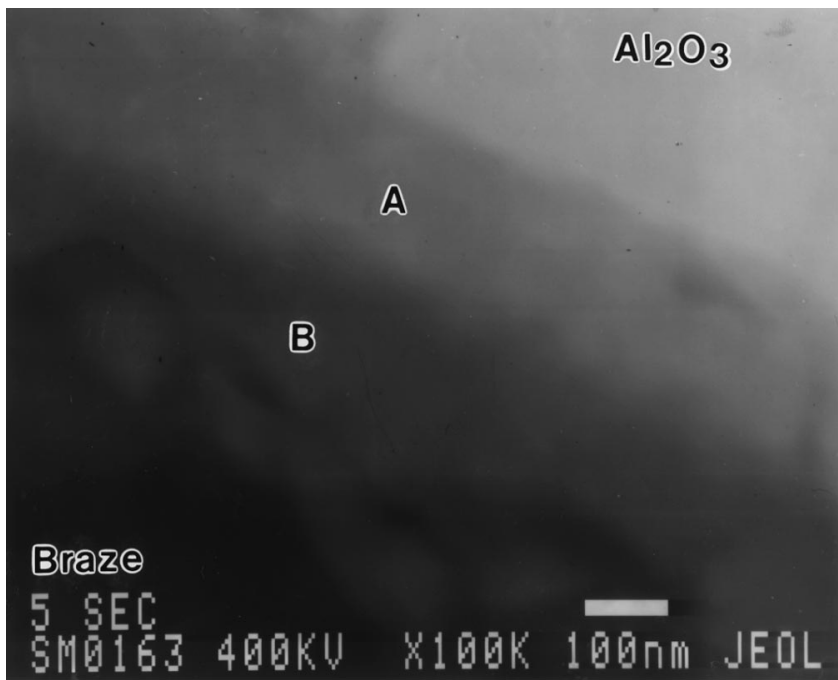

(a)

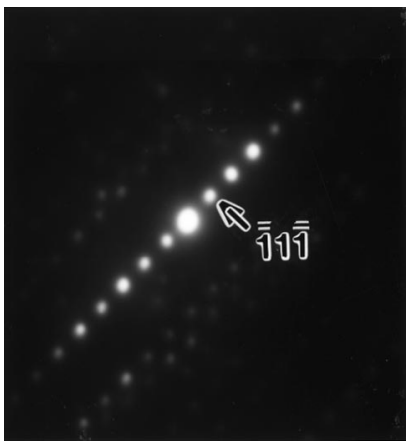

(b)

\begin{tabular}{ccccc}
\hline Point & $\mathrm{Cu}$ & $\mathrm{Ti}$ & $\mathrm{Al}$ & $\mathrm{Ag}$ \\
\hline $\mathrm{A}($ at \%) & 32.0 & 34.4 & 33.6 & - \\
$\mathrm{B}($ at \%) & 46.1 & 49.0 & 2.6 & 2.3 \\
\hline
\end{tabular}

(c)

Fig. 11-STEM + EDS analysis of the alumina/TICUSIL interface brazed at $900{ }^{\circ} \mathrm{C}$ for $5 \mathrm{~s}$ : (a) bright field of the two-layered interface, $(b)$ SADP analysis of point $\mathrm{B}$, and $(c)$ EDS analysis of point $\mathrm{A}$ and $\mathrm{B}$ marked in part (a).

silver-copper eutectic within 180 seconds brazing. The microstructure of the braze is approximately constant between 180 and 300 seconds.

2. The growth kinetics of the reaction layer obeys the parabolic law if the brazing time exceeds 120 seconds. It is not rate controlled by diffusion of reaction element(s) in 80 seconds brazing. It could be that the reaction layer involves the presence of Ti. Because of the inhomogeneity of Ti distribution in the braze alloy, $\mathrm{Ti}$ is not dissolved completely in the melt for the first 40 seconds.

3. A sessile drop experiment was performed by using a traditional vacuum furnace at the heating rate of $10{ }^{\circ} \mathrm{C} /$ min for $880{ }^{\circ} \mathrm{C}, 890{ }^{\circ} \mathrm{C}$, and $900{ }^{\circ} \mathrm{C}$. The wetting angle rapidly decreases within 150 seconds, especially the first 0 to 80 seconds, then stabilizes after 600 seconds at 900 ${ }^{\circ} \mathrm{C}$. The wetting angle tested at $900{ }^{\circ} \mathrm{C}$ is 5 to $20 \mathrm{deg}$ lower than that of the specimen tested at $880{ }^{\circ} \mathrm{C}$.

4. $\mathrm{The} \mathrm{Ti}_{3}(\mathrm{Cu}, \mathrm{Al})_{3} \mathrm{O}$ phase is observed in the reaction layer and plays an important role in the early stage of reactive wetting. A two-layer structure is found at the reaction 


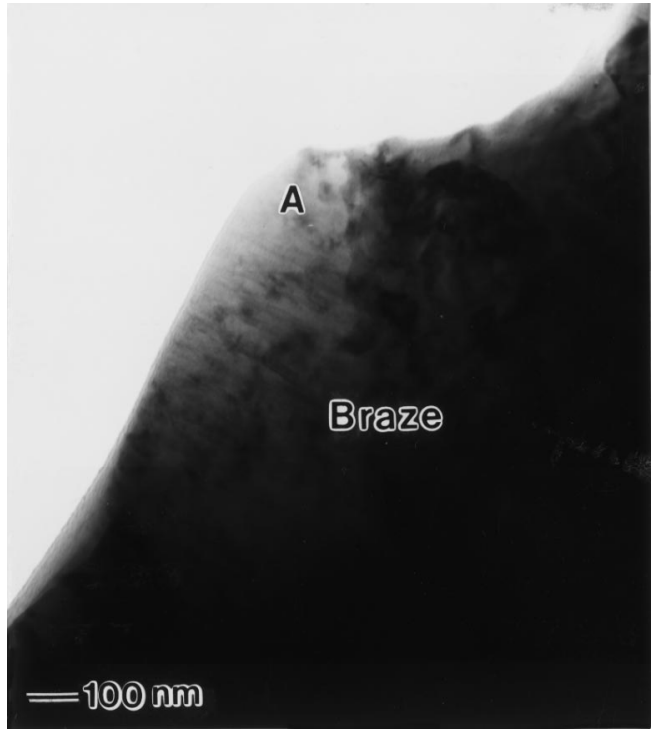

(a)

\begin{tabular}{ccccccc}
\hline & $\mathrm{Cu}$ & $\mathrm{Ti}$ & $\mathrm{Al}$ & $\mathrm{Ag}$ & $\mathrm{Fe}$ & $\mathrm{Ni}$ \\
\hline $\mathrm{at} \%$ & 42.8 & 46.3 & 6.5 & 1.6 & 1.8 & 1.0 \\
\hline
\end{tabular}

(b)

Fig. 12-STEM + EDS results of the alumina/TICUSIL interface brazed at $900{ }^{\circ} \mathrm{C}$ for $20 \mathrm{~s}$ : $(a)$ bright field and $(b)$ EDS analysis of point A in (a).

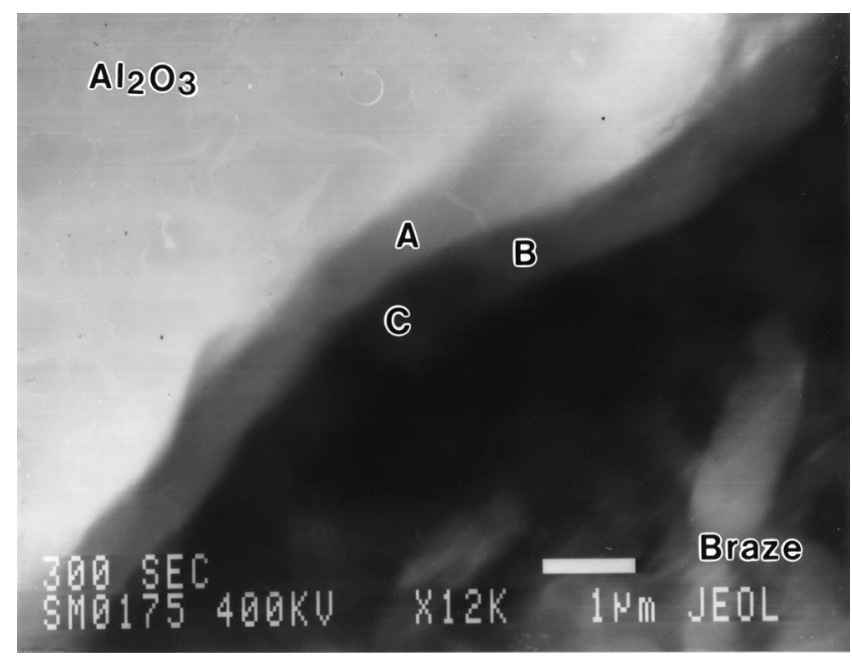

(a)

\begin{tabular}{ccccccc}
\hline Point & $\mathrm{Cu}$ & $\mathrm{Ti}$ & $\mathrm{Al}$ & $\mathrm{Ag}$ & $\mathrm{Fe}$ & $\mathrm{Ni}$ \\
\hline $\mathrm{A}($ at \%) & 6.9 & 38.5 & 18.0 & 1.0 & 17.7 & 18.0 \\
$\mathrm{~B}($ at \%) & 10.8 & 46.9 & - & 2.2 & 23.7 & 16.4 \\
$\mathrm{C}($ at \%) & 16.4 & 41.5 & 1.7 & 5.1 & 18.3 & 16.9 \\
\hline
\end{tabular}

(b)

Fig. 13-STEM + EDS results of the alumina/TICUSIL interface brazed at $900{ }^{\circ} \mathrm{C}$ for $300 \mathrm{~s}:(a)$ bright field; and (b) EDS analysis of point A, B, and $\mathrm{C}$ marked in (a).

interface brazed at $900{ }^{\circ} \mathrm{C}$ for 5 seconds. The reaction layer close to alumina contains a large amount of $\mathrm{Al}$, and the mass balance of the system is maintained. With

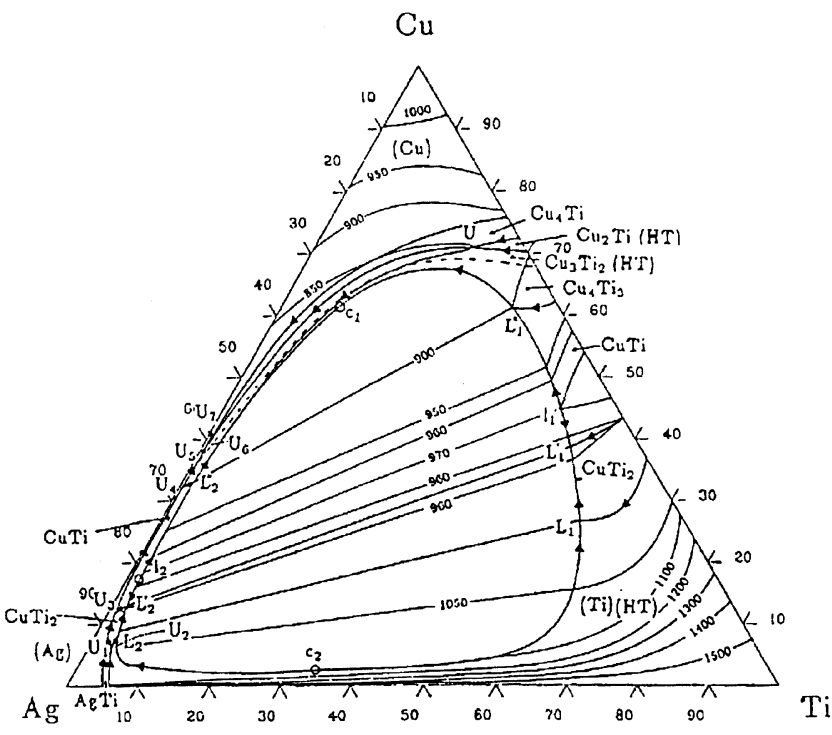

Fig. 14-Liquidus projection of $\mathrm{Ag}-\mathrm{Cu}-\mathrm{Ti}$ ternary phase diagram. ${ }^{[29]}$

increased brazing time, $\mathrm{Fe}$ and $\mathrm{Ni}$ atoms of alloy 42 can take part in the reaction layer, and the chemical composition of the reaction layer deviates from $\mathrm{Ti}_{3}(\mathrm{Cu}$, $\mathrm{Al})_{3} \mathrm{O}$.

\section{ACKNOWLEDGMENTS}

The authors gratefully acknowledge the financial support of this study by the National Science Council (NSC), Republic of China, under NSC Grant No. 88-2216-E002-026.

\section{REFERENCES}

1. E. Lugscheider and W. Tillmann: Mater. Manufacturing Processes, 1993, vol. 8, pp. 219-38.

2. G. Humpston and D.M. Jacobson: Principles of Soldering and Brazing, ASM INTERNATIONAL, Materials Park, OH, 1993, pp. 111-18.

3. M.M. Schwartz: Brazing, ASM INTERNATIONAL, Materials Park, OH, 1987, pp. 116-25.

4. M.M. Schwartz: Ceramic Joining, ASM INTERNATIONAL, Materials Park, OH, 1989, pp. 75-139.

5. A.P. Xian: J. Mater. Sci., 1993, vol. 28, pp. 1019-30.

6. A.K. Chattopadhyay and H.E. Hintermann: J. Mater. Sci., 1993, vol. 28, pp. 5887-93.

7. F. Tamai and M. Naka: J. Mater. Sci. Lett., 1996, vol. 15, pp. 1353-54.

8. N. Iwamoto, Y. Makino, and H. Miyata: Trans. JWRI, 1986, vol. 15(1), pp. 55-59.

9. M. Naka, H. Taniguchi, and I. Okamoto: Trans. JWRI, 1990, vol. 19 (2), pp. 29-34.

10. R.R. Kapoor and T.W. Eagar: Metall. Trans. B, 1989, vol. 20B, pp 919-24.

11. P.R. Chidambaram, G.R. Edwards, and D. L. Olson: Metall. Mater. Trans., 1994, vol. 25A, pp. 2083-90.

12. J.G. Li: Ceram. Int., 1994, vol. 20, pp. 391-412.

13. C. Odegard and A. Bronson: JOM, 1997, vol. 49 (6), pp. 52-54.

14. M. Naka, T. Tanaka, and I. Okamoto: Trans. JWRI, 1985, vol. 14 (2), pp. 85-91.

15. M. Naka, K. Sampath, I. Okamoto, and Y. Arata: Trans. JWRI, 1983, vol. 12 (2), pp. 181-83.

16. Y. Nakao, K. Nishimoto, and K. Saida: Trans. Jpn. Welding Soc., 1989, vol. 20 (1), pp. 66-76.

17. D.L. Olson et al.: ASM Handbook, vol. 6, Welding, Brazing and Soldering, ASM INTERNATIONAL, Materials Park, OH, 1993, pp. 948-60. 
18. M. Nomura, C. Iwamoto, and S.I. Tanaka: Acta Mater, 1999, vol. 47 (2), pp. 407-13.

19. R.E. Loehman and A.P. Tomsia: Acta Mater., 1992, vol. 40, Suppl., pp. S75-S83.

20. R.E. Loehman and A.P. Tomsia: J. Am. Ceram. Soc., 1994, vol. 77, pp. 271-74.

21. A. Meier, P.R. Chidambaram, and G.R. Edwards: Acta Mater, 1998, vol. 46, 12, pp. 4453-67.

22. P. Kritsalis, L. Coudurier, and N. Eustathopoulos: J. Mater. Sci., 1991, vol. 26 , pp. $3400-08$.

23. W. Tillmann and E. Lugscheider: J. Mater. Sci., 1996, vol. 31, pp. 445-52.

24. F. Tamai and K. Hirano: JSME Int. J., 1996, vol. 39A, pp. 613-19.

25. F. Ernst: Mater. Sci. Eng., R14, 1995, No. 3, pp. 97-156.

26. S.J. Lee, S.K. Wu, and R.Y. Lin: Acta Mater, 1998, vol. 46, pp. 1283-95.

27. S.J. Lee, S.K. Wu, and R.Y. Lin: Acta Mater, 1998, vol. 46, pp. 1297-1305.

28. T.B. Massalski et al.: Binary Alloy Phase Diagrams, 2nd ed., ASM INTERNATIONAL, Materials Park, OH, 1990, pp. 1494-96.

29. P. Villars, A. Prince, and H. Okamoto: Handbook of Ternary Alloy Phase Diagrams, ASM INTERNATIONAL, Materials Park, OH, 1996, pp. 2353-60.

30. T. Torvund, O. Grong, O.M. Akselsen, and J.H. Ulvensoen: J. Mater. Sci., 1997, vol. 32, pp. 4437-42.

31. D.B. Lee, J.H. Woo, and S.W. Park: Mater. Sci. Eng., 1999, vol. A268, pp. 202-07.
32. G. Wang and J.J. Lannutti: Metall. Mater. Trans. A, 1995, vol. 26A, pp. 1499-1506.

33. A. Mortensen, F. Hodaj, and N. Eustathopoulos: Scripta Mater, 1998, vol. 38, pp. 1411-17.

34. N. Eustathopoulos: Acta Mater, 1998, vol.46, pp. 2319-27.

35. D.R. Poirier and G.H. Geiger: Transport Phenomena in Materials Processing, TMS, Warrendale, PA, 1994, pp. 448-53.

36. M. Naka, J.C. Feng, and J.C. Schuster: Metal. Mater. Trans., 1997, vol. 28A, pp. 1385-90.

37. H. Xiong, C. Wan, and Z. Zhou: Metall. Mater. Trans. A, 1998, vol. 29A, pp. 2591-96.

38. E. Saiz, A.P. Tomsia, and R.M. Cannon: Acta Mater, 1998, vol. 46, pp. 2349-61

39. K.F. Lin and C.C. Lin: Scripta Mater, 1998, vol. 39, pp. 1333-38.

40. C. Iwamoto and S.I. Tanaka: Acta Mater., 1998, vol. 46, pp. 2381-86.

41. S.D. Peteves, M. Paulasto, G. Ceccone, and V. Stamos: Acta Mater, 1998, vol. 46, pp. 2407-14.

42. G. Dehm, C. Scheu, M. Ruhle, and R. Raj: Acta Mater, 1998, vol. 46, pp. 759-72.

43. A.H. Carim: Scripta Mater., 1991, vol. 25, pp. 51-54.

44. M. Paulasto and J. Kivilahti: J. Mater. Res., 1998, vol. 13, pp. 343-52.

45. F. Barbier, C. Peytour, and A. Revcolevschi: J. Am. Ceram. Soc., 1990, vol. 73, pp. 1582-86.

46. S. Suenaga, M. Nakahashi, M. Maruyama, and T. Fukasawa: J. Am. Ceram. Soc., 1997, vol. 80, pp. 439-44.

47. W. Byun and H. Kim: Scripta Mater, 1994, vol. 31, pp. 1543-47.

48. G.P. Kelkar and A.H. Carim: Mater. Lett., 1995, vol. 23, pp. 231-35. 